Section Editors

David C. Spencer, MD

Steven Karceski, MD

\title{
Mild cognitive impairment and progression to dementia New findings
}

John C.S. Breitner, MD, $\mathrm{MPH}$
WHAT WERE THE MAIN FINDINGS? Dr. Roberts and colleagues ${ }^{1}$ examined 2,719 elderly residents of Olmstead County, MN, every 15 months. The examinations showed that 534 persons had mild cognitive impairment, or MCI (see About MCI, following section). Some people had MCI when they were first seen. Others developed the condition later, so their problems were discovered during follow-up exams. The doctors knew from earlier studies that many people with MCI go on to develop dementia after a few years. But other people show little change over this time, while still others seem to recover or "revert" to cognitively normal when next examined. The doctors found that almost $40 \%$ of people with MCI "reverted" in this last way (a typical result). They wanted to know whether these "reverters" differed from other cognitively normal people in their risk of dementia. Over about 5 years of observation, they found that $65 \%$ of the "reverters" did go on to develop dementia. That was about 6 times the percentage of other cognitively normal people.

WHAT SETS THESE FINDINGS APART FROM EARLIER WORK? There aren't many reliable studies of what happens to people who "revert" from MCI to normality. Common sense suggests that these people must be different from others who are normal. We haven't been sure, though, just how different they are. This article offers important new information to answer that question. The study is especially valuable because its subjects came from a population. They weren't necessarily people who got treatment in a clinic or doctor's office. Data from clinic samples suggest what will happen over time to people who have sought medical attention for MCI. But they say little about what happens to the others (sometimes a majority) who haven't sought help. By contrast, this study describes "real" outcomes of people with $\mathrm{MCI}$ in a population.

Another strength of this study is that the researchers looked at medical records of people who didn't come back for their next scheduled exam. Here, the researchers had the advantage that people in Olmstead County get almost all their medical care from the Mayo Clinic. We know from other work that people who don't return for follow-up exams have more dementia than others. ${ }^{2}$ So not tracking people who don't return could lead to underestimates in the rate of onset of dementia. The Mayo Clinic records told Dr. Roberts and colleagues much of what they needed to know about these people.

WHY ARE THE FINDINGS IMPORTANT? Today, people routinely live into their 70 s, 80 s, or even 90s. At those ages, problems with memory and other cognitive abilities are so common they are often considered "normal for age." Unfortunately, many of these people go on to develop dementia. Between "benign" memory problems and dementia there are "in-between" conditions that appear to be the first signs of what may become dementia. This means that many people with MCI are actually in transition to dementia. But other people may have MCI caused by different underlying illnesses. If people with $\mathrm{MCI}$ have different underlying illnesses, we may want to treat them differently. We would want to know especially which people do progress to dementia but instead appear normal at their next exam. As Dr. Roberts and colleagues found, this outcome of MCI is quite common. In their study, it happened about $40 \%$ of the time. When doctors see this, a natural reaction is to think that they were "fooled" earlier into thinking the person had a serious illness. But this new article suggests they weren't fooled. Instead, they observed that cognition can be variable. This should surprise no one. All people, including those with MCI, have good days and bad days. What this article shows is that people with MCI also experience this sort of fluctuation. So it seems that those who "revert" to normal are often more like people whose MCI progresses to dementia than they are like people who didn't have cognitive problems in the first place.

\section{REFERENCES}

1. Roberts RO, Knopman DS, Mielke MM, et al. Higher risk of progression to dementia in mild cognitive impairment cases who revert to normal. Neurology 2014;82:317-325.

2. Norton M, Breitner JC, Welsh KA, Wyse BC. Characteristics of nonresponders in a community survey of the elderly. J Am Geriatr Soc 1994;42:1252-1256. 


\section{PATIENT PAGE}

Section Editors

David C. Spencer, MD

Steven Karceski, MD

\section{About mild cognitive impairment}

MCI means "mild cognitive impairment." People with MCI have cognitive problems that aren't as severe as those of dementia. Their main problem area is often with memory. But there may also be problems with finding words, and people may sometimes lose their sense of direction or where they are. When older people have very mild problems like these, doctors often reassure them that such things are "normal for age." But when the problems are more frequent or severe, they may cause concern. Especially if standard cognitive tests also reveal weaknesses that cause the problems, we may say that a person has MCI. The greatest worry is that MCI may be the "first sign" of more serious difficulties, including Alzheimer dementia. That worry has grown as recent studies have shown that people with MCI often develop dementia over the next few years.

Today we understand that Alzheimer dementia appears only after a decade or more of brain degeneration (preclinical Alzheimer disease). So we worry that people with MCI may have brain degeneration that can be quite advanced. In fact, several careful studies have shown that the brains of people with MCI can have all the changes found in Alzheimer dementia. ${ }^{1,2}$ And yet follow-up studies of people with MCI often show that they are no worse after a year or 2. Some people may even seem to do better.

These findings can seem puzzling at first but they probably happen for 2 fairly simple reasons. First, we need to remember that MCI can be caused by many health problems other than neurodegenerative diseases. These other problems don't usually end up causing dementia. Second, we are learning that many factors affect the severity of symptoms that result from neurodegeneration. Some of these factors can be biological, like physical health or nutrition, but others like emotional distress or mood are more puzzling. We still have much to learn about the links between neurodegenerative change and cognitive illness, including not only dementia but also MCI.

\section{FOR MORE INFORMATION}

AAN Patients and Caregivers site

http://patients.aan.com/go/home

National Institute of Mental Health (NIMH)

http://www.nimh.nih.gov

Alzheimer's Association

http://www.alz.org

National Family Caregivers Association

http://www.thefamilycaregiver.org

\section{REFERENCES}

1. Stephan BC, Hunter S, Harris D, et al. The neuropathological profile of mild cognitive impairment (MCI): a systematic review. Mol Psychiatry 2012;17:1056-1076.

2. Schneider JA, Arvanitakis Z, Leurgans SE, Bennett DA. The neuropathology of probable Alzheimer disease and mild cognitive impairment. Ann Neurol 2009;66:200-208. 


\title{
Neurology
}

\author{
Mild cognitive impairment and progression to dementia: New findings \\ John C.S. Breitner \\ Neurology 2014;82;e34-e35 \\ DOI 10.1212/WNL.0000000000000158
}

This information is current as of January 27, 2014

Updated Information \&
Services

References

Subspecialty Collections

Permissions \& Licensing

Reprints including high resolution figures, can be found at: http://n.neurology.org/content/82/4/e34.full

This article cites 4 articles, 1 of which you can access for free at: http://n.neurology.org/content/82/4/e34.full\#ref-list-1

This article, along with others on similar topics, appears in the following collection(s):

All Cognitive Disorders/Dementia

http://n.neurology.org/cgi/collection/all_cognitive_disorders_dementia Assessment of cognitive disorders/dementia

http://n.neurology.org/cgi/collection/assessment_of_cognitive_disorder s_dementia

Cognitive aging

http://n.neurology.org/cgi/collection/cognitive_aging

MCI (mild cognitive impairment)

http://n.neurology.org/cgi/collection/mci_mild_cognitive_impairment

Information about reproducing this article in parts (figures,tables) or in its entirety can be found online at:

http://www.neurology.org/about/about_the_journal\#permissions

Information about ordering reprints can be found online:

http://n.neurology.org/subscribers/advertise

Neurology ${ }^{\circledR}$ is the official journal of the American Academy of Neurology. Published continuously since 1951, it is now a weekly with 48 issues per year. Copyright () 2014 American Academy of Neurology. All rights reserved. Print ISSN: 0028-3878. Online ISSN: 1526-632X.

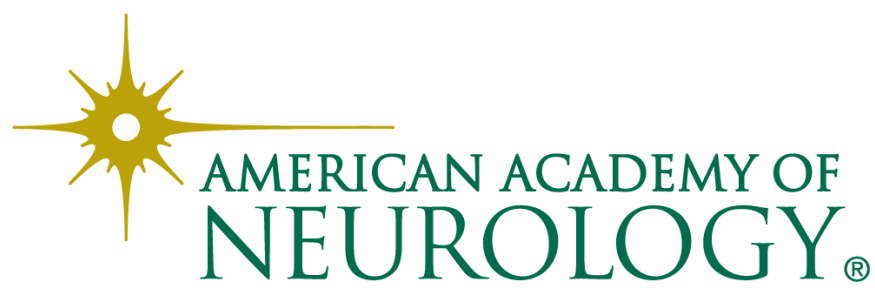

